\title{
Analysis of Restaurant Business Strategy in Developing Business using SWOT Analysis
}

\author{
Tya Wildana Hapsari Lubis ${ }^{1}$, Yeni Absah ${ }^{1}$ and Arlina Nurbaity Lubis ${ }^{1}$ \\ \{tyalubis71@gmail.com \\ Universitas Sumatera Utara, Medan, Indonesia
}

\begin{abstract}
This study aims to find out how the strategy of a restaurant business in developing its business. This research is a qualitative descriptive study. The research sample is Reza's restaurant located on Jl. Pembangunan No. 91 Dr. Mansyur USU Medan. Data analysis techniques used descriptive statistics and SWOT analysis. Data collection uses observation techniques, questionnaires, and in-depth interviews. The results of the study revealed that Reza's restaurant is in a growing condition and requires two strategies, namely (1) intensive strategy, a strategy that can be done based on intensive strategies namely market penetration, market development, and product development. (2) Integrative strategies, strategies that can be carried out based on backward integration, future integration, and horizontal integration.
\end{abstract}

Keywords: SWOT analysis, Strategy, Business Development.

\section{Introduction}

A restaurant is a business that serves a variety of dishes and prepares a place to enjoy these dishes with the provisions of certain tariffs for service and food enjoyed. The restaurant specializes in the types of food served, for example, Padang restaurants, fast food restaurants, western food restaurants, Chinese food, food courts and so on. The existence of restaurants began to be known since the 9th century in the Middle East region before appearing in China and in the Islamic world in the middle Ages.

he restaurant is very helpful for people who do not have time to eat at home because of outside activities and other limitations that consumers have. One restaurant business that is the object of this research is the REZA Restaurant located at Jln. Development No.91 Dr. Mansyur USU, Medan. This restaurant has been established since early 2011 to date, founded by a housewife named Agung Imansyah. Restaurant opening hours from $06.00-21.00$ WIB and are open every day except public holidays. Ruman Makan REZA is domiciled near the University of North Sumatra so that the biggest consumers are students and workers around the restaurant environment. REZA restaurants provide various types of traditional Indonesian home cooking so that when consumers (especially students) consume food from this restaurant, they will feel food like at home, a varied menu and every hour changes to become a typical of REZA Restaurant.

The high competition at Jln. Pembangunan USU and the many innovations carried out by competitors both in offering food that is served and services that are more satisfying than existing competitors makes Reza restaurants have to think about the right strategy by paying 
attention to internal and external conditions in order to be able to compete and excel in competition. REZA Restaurant does not superiorl in competing because many competitor restaurants provide products that REZA Restaurants do not have so that the REZA Restaurant itself has experienced a decline in sales in the last few months. The decline in sales requires REZA Restaurants to have a competitive strategy and innovation in both the food products presented and the services that will be provided to consumers.

Table 1 : REZA Medan Restaurant Sales Data (2016)

\begin{tabular}{|c|c|c|c|c|}
\hline Month & $\begin{array}{c}\text { Total Opening Hours / } \\
\text { Month } \\
\end{array}$ & $\begin{array}{c}\begin{array}{c}\text { Average Sales (Per Pack) / } \\
\text { Month }\end{array} \\
\end{array}$ & $\begin{array}{c}\text { Average Selling } \\
\text { Price }\end{array}$ & $\begin{array}{c}\begin{array}{c}\text { Total Sales / } \\
\text { Month }\end{array} \\
\end{array}$ \\
\hline Maret & 496 Jam & 11.200 Pack & Rp. 8.500 / Pack & Rp. 95.200 .000 \\
\hline April & $480 \mathrm{Jam}$ & 11.353 Pack & Rp. $8.500 /$ Pack & Rp. 96.500 .500 \\
\hline Mei & 496 Jam & 11.259 Pack & Rp. $8.500 /$ Pack & Rp. 95.701 .500 \\
\hline Juni & $600 \mathrm{Jam}$ & 12.942 Pack & Rp. $8.500 /$ Pack & Rp. 110.001 .000 \\
\hline Juli & 496 Jam & 10.470 Pack & Rp. $8.500 /$ Pack & Rp. 88.995 .000 \\
\hline Agustus & 496 Jam & 10.329 Pack & Rp. $8.500 /$ Pack & Rp. 87.806 .829 \\
\hline $\begin{array}{c}\text { Septembe } \\
\mathrm{r}\end{array}$ & $480 \mathrm{Jam}$ & 10.142 Pack & Rp. $8.500 /$ Pack & Rp. 86.207 .000 \\
\hline Oktober & 496 Jam & 9.985 Pack & Rp. $8.500 /$ Pack & Rp. 84.872 .500 \\
\hline
\end{tabular}

REZA restaurants must have a business strategy, no longer just run a traditional business without a strategy to anticipate competitors and achieve competitive advantage in their business.

o achieve competitive advantage and formulate the right competitive strategy, it must be seen from the condition of the company by analyzing the internal and external factors of the company. According to Situmorang (2012), internal factors include strength, that is everything that is the company's advantage, and weakness is everything that is a weakness of the company. External factors include opportunities, which are all things that can be used by the company as an opportunity to increase revenue and threats, which are things that can hinder the company's performance. Analysis using external and internal factors is called the SWOT analysis.

SWOT analysis is used to establish a home business strategy in an effort to achieve goals and achieve competitive advantage from competitors in similar businesses.

\section{Literatur Review}

\subsection{Strategy Concept}

According to Coulter (Kuncoro, 2006), the strategy is a number of decisions and actions aimed at achieving goals and adjusting organizational resources with the opportunities and challenges faced in the industrial environment. According to Umar (2002), the strategy has a basis or scheme to achieve the intended goal, so it is basically a strategy to achieve a goal. Meanwhile, according to David (2010), strategic management is an art and knowledge to formulate, implement, and evaluate cross-functional decisions that enable the organization to achieve its objectives. The focus of strategic management lies in integrating management, marketing, finance / accounting, production / operations, research and development, and computer information systems to achieve organizational success. 


\subsection{SWOT analysis}

The environment faced by each company is divided into two, namely the environment within the company (internal) and the environment outside the company (external), (Pardede, 2010). The environment encompasses every tendency, strength, and event that arises in the company and influences the activities and success of the company, the external environment includes every tendency, strength, and event that arises outside the company and influences the success of the company.

SWOT stands for Strength, Weakness, Opportunity, Threat. SWOT analysis contains an evaluation of the company's internal factors in the form of strengths and weaknesses, and the company's external factors in the form of opportunities and challenges. So the strategy chosen must be in accordance with the conditions and capabilities of the company.

According to Rangkuti (2014), SWOT analysis is a systematic identification of various factors to formulate a company strategy. While according to Situmorang (2011), SWOT analysis is only useful if it is clearly determined in what business the company is operate, and towards which company leads its future and what measures are used to assess the success of the company's management in realizing its vision.

Table 2: SWOT Matrix

\begin{tabular}{|c|c|c|}
\hline & & WEAKNESS (W) \\
\hline OPPORTUNITIES (O) & A & B \\
& STRATEGY S & STRATEGYWO \\
\hline THREATS (T) & C & D \\
& STRATEGY & STRATEGYWT \\
\hline
\end{tabular}

\section{Method of Research}

This research is descriptive qualitative to reveal the facts, circumstances and phenomena of the variables studied at the Reza Restaurant. Data collection is used survey method, interview and observation. The study was conducted at the Reza Restaurant located on jalan Pembangunan no. 91 Dr.Mansyur Medan The study was conducted in March 2017 to June 2017. The study population was the informant who would be interviewed in depth, namely the owners and workers, customers and competitors of Rumah Reza. Data analysis techniques are descriptive statistics and data triangulation that combines several data from various sources through participatory observation, in-depth interviews and documentation. In addition, a SWOT Analysis is used to determine the strategies needed by businesses in developing their business.

\section{Result And Discussion}

Reza's restaurant opened for the first time in 2011. The number of informants in this study were 27 people, 1 person as owner, 10 workers, 10 permanent customers and new customers, and there were 6 competitors who were customers of other restaurants adjacent to Reza's restaurant. 


\subsection{Discussion}

SWOT analysis using SWOT matrix is an analysis carried out to find out various internal factors, namely Strength and Weakness which are presented together with an analysis of various external factors, namely opportunities for Opportunities and Threats. This matrix provides a clear and detailed description of the strengths and weaknesses and opportunities and threats faced by Reza's restaurant. SWOT analysis will give birth to a strategy that is considered capable of helping restaurant owners to develop their businesses because they are able to overcome the weaknesses and threats faced and develop the potential strengths and opportunities of restaurants.

The SWOT matrix provides 4 columns of solutions for Reza restaurants to carry out their business development strategies, namely the SO strategy (strength - opportunities), ST (strength - threats) strategy, WO (weakness - opportunities) strategy, and WT (weakness threats) strategy. This matrix can be explained in Table 3, as follows:

Table 3: SWOT Matrix Analysis of the REZA Restaurant

\begin{tabular}{|c|c|c|}
\hline \multirow[t]{3}{*}{ IFAS } & STRENGHTS (S) & WEAKNESS (W) \\
\hline & $\begin{array}{l}\text { 1. Location } \\
\text { 2. The product is in } \\
\text { accordance with the } \\
\text { customer's wishesPromosi } \\
\text { yang dilakukan dari mulut } \\
\text { ke mulut } \\
\text { 3. The owner really } \\
\text { maintains customer } \\
\text { relationships } \\
\text { 4. Early opening hours } \\
\text { compared to competitors }\end{array}$ & $\begin{array}{l}\text { 1. Service to customers is not } \\
\text { optimalBukti fisik Rumah } \\
\text { Makan REZA yang belum } \\
\text { memadai } \\
2 . \quad \text { Human resources are } \\
\text { inadequate }\end{array}$ \\
\hline & & \\
\hline OPPORTUNITIES & STRATEGI SO & STRATEGI WO \\
\hline $\begin{array}{l}\text { 1. } \begin{array}{l}\text { Construction of new } \\
\text { boarding rooms for } \\
\text { students }\end{array} \\
\text { 2. REZA restaurants are } \\
\text { adjacent to many other } \\
\text { businesse } \\
\text { 3. USU student } \\
\text { organization activities }\end{array}$ & $\begin{array}{l}\text { 1. Expand the market by } \\
\text { opening a new branch } \\
\text { 2. Market penetration to } \\
\text { increase sales } \\
\text { 3. Always supervise } \\
\text { management } \\
\text { 4.Establish good relations } \\
\text { with business owners } \\
\text { around the REZA } \\
\text { Restauran } \\
\text { 5.Provides bonuses to } \\
\text { students who bring } \\
\text { prospective customers }\end{array}$ & $\begin{array}{l}\text { 1. Recruit additional workers } \\
\text { 2. Improve services } \\
\text { 3. Fix and complete physical } \\
\text { evidence of Restaurant }\end{array}$ \\
\hline
\end{tabular}




\begin{tabular}{|l|l|l|}
\hline THREATS (T) & \multicolumn{1}{|c|}{ STRATEGI ST } & \multicolumn{1}{c|}{ STRATEGI WT } \\
\hline $\begin{array}{l}\text { 1.Starting new competitor } \\
\text { 2.Increase in prices of food } \\
\text { staples }\end{array}$ & $\begin{array}{l}\text { 1.Always make product } \\
\text { innovations on traditional } \\
\text { 3.Land status of buildings } \\
\text { that are still contracted } \\
\text { 2.. Determine the selling price } \\
\text { policy or product quality } \\
\text { when the price of food staples } \\
\text { rises }\end{array}$ & $\begin{array}{l}\text { 1.Improve the service system } \\
\text { 2.Purchase land for business or pay } \\
\text { a contract per 5 years } \\
\text { 3.Look for a new location that is } \\
\text { easy to open to open a branch } \\
\text { 3. Clarify the standardization of the } \\
\text { duties of workers }\end{array}$ \\
& $\begin{array}{l}\text { promotional activities } \\
\text { 4.Improve the nature of kinship } \\
\text { in establishing relationships } \\
\text { with consumers }\end{array}$ & \\
\hline
\end{tabular}

Analysis with SWOT matrix produces four strategies including :

\section{SO Strategy:}

It is a strategy that uses the internal strength of a restaurant to take advantage of opportunities. The strategy that can be done is to expand the market by opening a new restaurant branch, doing promotions in serving customers, especially for permanent customers who are catering. The owner must also supervise restaurant management, teach employees to improve good service to customers and make customers comfortable, create a comfortable restaurant atmosphere while waiting or while eating, build good relationships with competitors, create meal promo packages that attract consumers, provide bonus for students, as well as consumers who order large quantities and build good emotional and family relationships with consumers.

\section{WO Strategy}

It is a strategy to use opportunities to overcome internal weaknesses in restaurants. The alternative strategy is to find additional workers so that the results of the work are more effective, improve the better service to consumers, improve and complete the physical evidence of restaurants. The owner can also do online promotions to get more customers, renovate buildings with better appearance, add air conditioning facilities, provide uniforms to workers, have transportation equipment to transport food raw materials and monitor the entire process from several branches of restaurants.

3. ST Strategy

Is a strategy to reduce the consequences of various threats received by restaurants. Some strategies that can be done by innovating the results of food from various regional cuisines, then setting a selling price that matches the taste, quality and ability of the dominant customers are students. The owner can also determine the selling price or product quality policy when the price of food staples rises, increasing electronic media in promotional activities. provide benefits more than the prices incurred by consumers such as fresh vegetables and cold mineral water. The owner must also increase customer loyalty by establishing good communication, improving services by giving direction to workers, providing products offered such as juice, cut fruit and others alternative foods. 


\section{WT Strategy}

A strategy to minimize weaknesses and avoid threats. Strategies that can be done include increasing the role of promotional media, improving the service system provided, providing training to workers on how to better serve consumers, finding alternative parking for consumers, buying land for business or paying a contract per 5 years, looking for a new location that is easy to reach to open the REZA Restaurant branch, clarifying the standardization of the tasks of the workers, improving the morning hours service by recruiting morning special workers.

In accordance with the research conducted by (Sholihin, 2014) which is the right strategy to be applied by woven sarong companies that are aggressive strategies (advanced development), the right strategy is used by the woven sarong fabric company with the right strategy to be applied in REZA Restaurant , these two businesses are in the same position namely quadrant I. Al Rafaie (2016) also mentions in his research that the right strategy to be applied by cosmetics companies is an aggressive strategy, this strategy is right to be used by cosmetic companies with the right strategy for applied to REZA Restaurant.

In conditions of growing and building, Reza's restaurant has two strategies, namely (1) intensive strategy, a strategy that can be carried out based on intensive strategies namely market penetration, market development, and product development. (2) integrative strategies, strategies that can be carried out based on integrative strategies, namely backward integration, future integration, and horizontal integration. Therefore, the short-term strategy of Reza's restaurant is:

1. Making promos in serving consumers

2. Supervise restaurant management so that all parties carry out their duties correctly

3. Improve the ability of workers / waitresses to serve and make consumers feel comfortable when eating

4. Creating a comfortable restaurant

5. Establish good relations with business owners around the Reza restaurant, especially with competitors.

6. Creating a catering package for household consumers

7. Giving bonuses to customers who bring new customers

8. Give bonuses to students

9. Start using promotions using the internet to introduce dishes

10. Complete facilities to support business success.

The long-term strategy that can be done is:

1. Expand the market by opening a new branch

2. Develop new products or menus

3. Making business innovations following changes in consumer tastes

4. If you have more money, the entrepreneur can pay a longer shop rental contract.

\section{CONCLUSIONS}

The results of the SWOT matrix produce an S-O strategy that allows REZA Restaurants to determine the most appropriate and most suitable strategy. The S-O strategy utilizes the internal strength of the REZA Restaurant to take advantage of the opportunities.

\section{Acknowledgements}


Researchers would like to thank all the mentors who helped researchers complete the research well. Researchers hope that the results of this study will become input for business owners to develop their businesses. Even this result is also an input for all parties who need a strategy in developing a restaurant business.

\section{References}

[1] A, Al-Refaie. (2016). Integration of SWOT and ANP For Effective Strategic Planning In The Cosmetic Industry. Advance in Production Engineering and Management Journal. 11(1).ISSN 1854-6250.

[2] Baghai, Mehrdad, dkk. (2000). The Alchemy of Growth: Kickstarting and Sustaining Growth in Your Company. London: Texere.

[3] Chang, Che-Wei. and Liao Liao, Chia Chun. 2013. Applying SWOT Analysis to Explore Taiwan Foundry Industry Management Strategy. International Journal of Innovation, Management and Technology. 4(1)

[4] David, Fred R. (2010). Strategic Management Concept. Jakarta : PT. Prenhallindo

[5] David, Fred R. dan David, Forest R. (2016). Strategic Management. $15^{\text {th }}$ edition. Jakarta: Salemba Empat

[6] Dilek, Serkan. And Kesgingöz, Hayrettin. (2016). SWOT Analysis of Safranbolu City in Terms of Tourism. Journal of Research in Business \& Social Science. 5(1). ISSN: $2147-$ 4486.

[7] Hardiyansyah, Andri. (2015). Analysis of Marketing Strategy for Wet Noodle Business (Case Study in PD. LUGINA-Garut). Kalibrasi Journal of Sekolah Tinggi Teknologi Garut. 13(1). ISSN : 2302-7320.

[8] Kotler, Philip dan Hermawan Kertajaya. (2004). Rethinking Marketing Suistanable Market-ing Entreprice di Asia. Jakarta: PT.Indeks

[9] Pardede, Pontas M. (2010). Strategic Management \& Corporate Policy. 7th edition. Medan: Mitra Wacana Media

[10] Rangkuti, Freddy. (2013). Business Case Dissecting Technique SWOT Analysis. Jakarta: Gramedia Pustaka Utama.

[11] Rangkuti, Freddy. (2016). SWOT Balanced Scorecard. Jakarta: Gramedia Pustaka Utama.

[12] Sancoko, Aldo Hardi. (2015). Food and Beverage Business Development Strategy at Surabaya Time To Eat Depot. Journal of Business Management. Universitas Kristen Petra. 3(1).

[13] Sari, Dita fitrisia. (2014). Efforts to Achieve Excellence Competing Using SWOT Analysis at Salon Michi. Thesis: Universitas Sumatera Utara.

[14] Suwarsono, Muhammad. (2013). Strategic Management Concepts and Analysis Tools. Yogyakarta: Sekolah Tinggi Ilmu Manajemen YKPN

[15] Trout, J dan Rivkin, S. (2010). Marketing Era Competition, Change, and Crisis, Repositioning. McGraw Hill Professional. 